\title{
FAKTOR-FAKTOR YANG MEMENGARUHI PENGUNGKAPAN LAPORAN KEBERLANJUTAN (STUDI PADA PERUSAHAAN NON KEUANGAN YANG TERDAFTAR DI BURSA EFEK INDONESIA PERIODE 2016-2017)
}

\begin{abstract}
The research objective is to determine the effect of sales growth, profitability, corporate governance, and company size simultaneously and partially on the sustainability report of non-financial companies listed on the Indonesia Stock Exchange for the period of 2016-2017. The method used is panel data regression analysis and the results of the study found that simultaneous sales growth, profitability, corporate governance, and company size influence the disclosure of sustainability reports. Partial testing only profitability and company size that affect the disclosure of sustainability reports.
\end{abstract}

\author{
Arini Jembar Rahayu', \\ Cahyaningsih $^{2}$ \\ ${ }^{1}$ Prodi S1 Akuntansi, \\ Fakultas Ekonomi dan \\ Bisnis, Universitas Telkom \\ ${ }^{2}$ Dosen Fakultas Ekonomi \\ dan Bisnis, Universitas \\ Telkom \\ Keywords: Profitability, Sales \\ Growth, Firm Size, Corporate \\ Governance,Sustainability \\ Report
}

ABSTRAK: Tujuan penelitian adalah untuk mengetahui pengaruh pertumbuhan penjualan, profitabilitas, tata kelola perusahaan, dan ukuran perusahaan secara simultan serta parsial terhadap laporan keberlanjutan perusahaan non keuangan yang terdaftar di Bursa Efek Indonesia periode 2016-2017. Metode yang digunakan yaitu analisis regresi data panel dan hasil penelitian menemukan bahwa secara simultan pertumbuhan penjualan, profitabilitas, tata kelola perusahaan, dan ukuran perusahaan berpengaruh terhadap pengungkapan laporan keberlanjutan. Pengujian secara parsial hanya profitabilitas dan ukuran perusahaan yang berpengaruh terhadap pengungkapan laporan keberlanjutan.
Kata Kunci: Profitabilitas, Pertumbuhan Penjualan, Ukuran Perusahaan, Tata Kelola Perusahaan, Laporan Keberlanjutan

\section{Pendahuluan}

Laporan keberlanjutan saat ini semakin mendapat perhatian dalam pelaksanaan praktik bisnis global. Kurniawan (2017) menyatakan bahwa perusahaan yang mengutamakan program keberlanjutan terstruktur akan memiliki nilai atau reputasi perusahaan yang positif, sehingga akan mendorong para investor untuk menanamkan modalnya di perusahaan tersebut. Pemerintah membuat regulasi mengenai laporan keberlanjutan dengan menetapkan aturan yang dicantumkan dalam Undang-Undang Nomor 40 Tahun 2007 tentang Perseroan Terbatas. UndangUndang tersebut menjelaskan aturan-aturan yang berkaitan dengan implementasi laporan keberlanjutan di Indonesia. Faktor pendukung untuk terlaksananya pengungkapan laporan keberlanjutan adalah adanya pandangan baru mengenai paradigma bisnis saat ini yaitu triple $P$ (Profit, People, Planet). Pandangan tersebut mendorong perusahaan untuk tidak lagi berfokus hanya pada pelaporan keuangan saja, melainkan juga laporan yang berhubungan dengan stakeholder, masyarakat, dan lingkungan sekitar perusahaan beroperasi. Informasi mengenai tiga aspek tersebut dapat disampaikan melalui laporan keberlanjutan.

Kementerian Lingkungan Hidup dan Kehutanan (KLHK) menerima laporan terkait pencemaran praktik tidak bertanggung jawab dari perusahaan dalam menjalankan operasinya. Laporan tersebut diantaranya, pada tahun 2018, PT Bukit Asam dilaporkan 
telah mencemari Sungai Kiahan yang diakibatkan dari eksplorasi kegiatan tambang PT Bukit Asam di Penambangan Bangko Barat, Sumatera Selatan. Kegiatan tambang tersebut mengakibatkan warna air dari Sungai Kiahan berwarna keruh bahkan cenderung hitam sehingga Sungai Kiahan tidak dapat dimanfaatkan oleh masyarakat sekitarnya lagi (Enim, 2018)

Laporan kerusakan lingkungan lainnya juga terjadi di kawasan Teluk Balikpapan yang dilakukan oleh PT Semen Indonesia. Perusahaan diduga telah melakukan kegiatan operasional unit packing plant (pabrik pengantongan atau pengemasan) semen di sekitar wilayah Karingau, Teluk Balikpapan. Dampak yang ditimbulkan dari operasional tersebut adalah melanggar garis sipadan, mengubah kawasan mangrove, dan berubahnya fungsi sungai sehingga tidak bisa digunakan oleh masyarakat (Luqman, 2017).

Perusahaan sebaiknya melakukan tindakan yang dapat mendorong terlaksananya pengungkapan laporan keberlanjutan sesuai dengan standar GRI 4, satu diantara caranya adalah dengan mempertimbangkan dan memerhatikan hasil dari profitabilitas, ukuran perusahaan, pertumbuhan penjualan, dan tata kelola perusahaan. Berdasarkan penelitian sebelumnya yang menggunakan laporan keberlanjutan sebagai variabel dependen dengan profitabilitas, ukuran perusahaan, pertumbuhan penjualan, dan tata kelola perusahaan sebagai variabel independen menunjukkan inkonsistensi dalam hasil penelitiannya. Penelitian yang dilakukan oleh Munsaidah (2016) serta Ulfa (2009) yang menjelaskan hubungan positif antara profitabilitas dan ukuran perusahaan terhadap pengungkapan CSR perusahaan, sedangkan menurut Sri dan Syam (2013) serta Panggabean (2017) menjelaskan bahwa profitabilitas tidak berpengaruh terhadap pengungkapan CSR.

Penelitian menurut Indraswari dan Astika (2015) serta Badjuri (2011) menjelaskan adanya hubungan positif antara ukuran perusahaan terhadap praktik pengungkapan laporan keberlanjutan, sedangkan menurut Maryani (2014) menjelaskan bahwa ukuran perusahaan tidak berpengaruh terhadap pengungkapan CSR perusahaan.

Penelitian menurut Badjuri (2011) menjelaskan adanya hubungan positif antara tata kelola perusahaan terhadap praktik pengungkapan laporan keberlanjutan, sedangkan menurut Panggabean (2017) dan Aziz (2014) menjelaskan bahwa tata kelola perusahaan tidak berpengaruh terhadap pengungkapan laporan keberlanjutan.

Penelitian menurut Munsaidah (2016) menjelaskan adanya hubungan positif antara pertumbuhan penjualan terhadap praktik pengungkapan laporan keberlanjutan, sedangkan menurut Indraswari dan Mimba (2017) serta Ulfa (2009) menjelaskan bahwa pertumbuhan penjualan tidak berpengaruh terhadap pengungkapan laporan keberlanjutan.

\section{Pengembangan Hipotesis}

\section{Teori Legitimasi}

Teori legitimasi menyatakan bahwa organisasi berusaha untuk mendapatkan jaminan bahwa operasi mereka berjalan dengan berkelanjutan dan tetap berada dalam norma yang berlaku di lingkungan masyarakat sekitar, sehingga dapat tercapainya pengungkapan informasi sosial perusahaan dalam laporan keberlanjutan. Perusahaan mengharapkan timbal balik berupa legitimasi dari masyarakat yang akan berdampak pada keberlangsungan hidup perusahaan. Legitimasi dianggap sebagai cara untuk mempertahankan keberlangsungan hidup suatu organisasi yang dicapai melalui tindakan organisasi yang sesuai aturan dan dapat diterima secara luas oleh masyarakat (Chariri dan Ghozali, 2013).

\section{Laporan Keberlanjutan}

Standar pengungkapan laporan keberlanjutan yang berkembang di Indonesia mengacu pada GRI (Global Reporting Intiatives). Standar GRI berfokus 
pada kinerja ekonomi, sosial, dan lingkungan perusahaan. Pengungkapan di GRI 4 ada 91 indikator diantaranya, sembilan indikator kinerja, 34 indikator kinerja lingkungan hidup, 16 indikator kinerja praktek ketenagakerjaan dan lingkungan kerja, 12 indikator kinerja hak asasi manusia, sebelas indikator kinerja masyarakat dan sembilan indikator kinerja tanggung jawab produk.

\section{Profitabilitas terhadap Laporan Keberlanjutan}

Profitabilitas dapat diartikan sebagai kemampuan perusahaan uHt2k menghasilkan laba (Hery, 2016). Perusahaan yang dapat memaksimalkan kemampuannya dalam menghasilkan laba akan memiliki fokus yang lebih terhadap alokasi dana keberlanjutan untuk melakukan tanggug jawab sosialnya. Perusahaan yang melakukan aktivitas tanggung jawab sosial akan lebih menarik bagi para investor untuk menanamkan modalnya. Oleh karena itu, perusahaan akan mendapat perhatian lebih dari investor dalam pelaporan informasi tanggug jawab sosialnya dan juga sebagai bentuk tanggung jawab perusahaan terhadap para pemangku kepentingan dalam melaporkan pengungkapan informasi perusahaannya. Penelitian yang dilakukan oleh Munsaidah (2016) dan Ulfa (2009) menjelaskan bahwa profitabilitas berpengaruh positif terhadap pengungkapan laporan keberlanjutan.

\section{H1: Profitabilitas berpengaruh positif terhadap pengungkapan laporan keberlanjutan.}

\section{Ukuran Perusahaan terhadap Laporan Keberlanjutan}

Ukuran perusahaan merupakan skala dari besar kecilnya suatu perusahaan (Maiyarni, 2014). Perusahaan besar yang telah terdaftar di pasar modal akan lebih mudah di awasi kegiatannya oleh para pemegang saham serta dalam praktik operasinya akan mendapat perhatian lebih dari masyarakat sekitarnya (Sri dan Syam, 2015). Sebagai bentuk tanggung javhB: perusahaan terhadap para pemegang saham dan masyarakat sekitar, maka perusahaan akan melakukan penyampaian informasi melalui laporan keberlanjutan perusahaan.
Hal ini dikarenakan dalam laporan keberlanjutan terdapat informasi terkait program sosial dan lingkungan perusahaan yang telah direalisasikan oleh perusahaan. Uraian tersebut menjelaskan bahwa ukuran perusahaan berpengaruh positif terhadap pengungkapan laporan keberlanjutan. Penelitian yang dilakukan oleh Sri dan Syam (2015) dan Maiyarni (2014) menjelaskan bahwa adanya pengaruh ukuran perusahaan dan profitabilitas terhadap laporan keberlanjutan.

\section{Ukuran perusahaan berpengaruh positif terhadap pengungkapan laporan keberlanjutan.}

\section{Pertumbuhan Penjualan terhadap Laporan Keberlanjutan}

Pertumbuhan penjualan merupakan gambaran kekuatan perusahaan untuk bertahan hidup (Indraswari dan Astika, 2017). Perusahaan dengan kemampuan bertahan hidup yang berkelanjutan akan terlihat lebih unggul dan mampu menghadapi persaingan serta memperoleh respon positif dari masyarakat maupun para pemangku kepentingan. Perusahaan akan medapatkan perhatian lebih dari para pemangku kepentingan sehingga diprediksi perusahaan yang mempunyai kesempatan pertumbuhan yang lebih tinggi memiliki tanggung jawab sosial yang tinggi pula (Ulfa, 2009). Oleh karena itu, perusahaan dapat menyampaikan informasi mengenai tanggung jawab sosialnya melalui pengungkapan laporan keberlanjutan perusahaan. Berdasarkan uraian tersebut dapat disimpulkan bahwa pertumbuhan penjualan perusahaan berpengaruh positif terhadap tingkat pengungkapan laporan keberlajutan. Penelitian yang dilakukan oleh Munsaidah (2016) menjelaskan bahwa pertumbuhan perusahaan (growth) berpengaruh positif terhadap tingkat pengungkapan laporan keberlanjutan perusahaan.

Pertumbuhan penjualan berpengaruh positif terhadap pengungkapan laporan keberlanjutan. 


\section{Tata Kelola Perusahaan terhadap Laporan} Keberlanjutan

Dewan komisaris merupakan dewan yang memiliki tugas untuk melakukan monitor terhadap manajemen dalam mengelola perusahaan. Berdasarkan penjelasan tersebut, dewan komisaris memiliki peranan penting dalam pengambilan keputusan perusahaan dan dianggap mampu memberikan monitor yang positif dalam mengawasi kegítabel manajemen (Badjuri, 2011). Semakin besar ukuran dewan komisaris maka komposisi keahlian dan pengalaman yang dimiliki dewan komisaris akan semakin meningkat. Dewan komisaris yang memiliki keahlian dan pengalaman mengenai pentingnya laporan keberlanjutan perusahaan dapat memberikan saran dan monitoring yang baik terhadap menejemen mengenai penyampaian informasi yang terdapat di dalam laporan keberlanjutan. Berdasarkan uraian tersebut dapat disimpulkan bahwa dewan komisaris berpengaruh positif terhadap tingkat pengungkapan laporan keberlanjutan. Penelitian yang dilakukan oleh Badjuri (2011) menjelaskan bahwa tata kelola perusahaan berpengaruh positif terhadap pengungkapan laporan keberlanjutan.

H4: Tata kelola perusahaan berpengaruh positif terhadap pengungkapan laporan keberlanjutan. $\longrightarrow=$ Pengaruh secara simultan

\section{Metode, Data, dan Analisis}

Penelitian ini menggunakan metode kuantitatif untuk menguji hipotesis. Jenis data yang digunakan adalah data panel, sehingga teknik analisis data menggunakan model regresi data panel.

1 Kriteria Pengambilan Sampel dengan Purposive Sampling

\begin{tabular}{lc}
\multicolumn{1}{c}{ Kriteria } & Jumlah \\
\hline Perusahaan non keuangan & 460 \\
yang terdaftar di Bursa Efek & \\
Indonesia (BEI) periode 2016 \\
sampai 2017. \\
$\begin{array}{l}\text { Perusahaan non keuangan } \\
\text { yang tidak mengungkapkan }\end{array}$ \\
laporan keberlanjutan periode \\
2016 sampai 2017. \\
Total Perusahaan
\end{tabular}

Sumber: Data yang telah diolah (2019)

Variabel yang digunakan meliputi variabel dependen yaitu laporan keberlanjutan dan variabel independen yaitu profitabilitas, pertumbuhan penjualan, ukuran perusahaan, dan tata kelola perusahaan. Tabel 2 menyajikan operasionalisasi variabel penelitian.

Tabel 2 Operasionalisasi Variabel

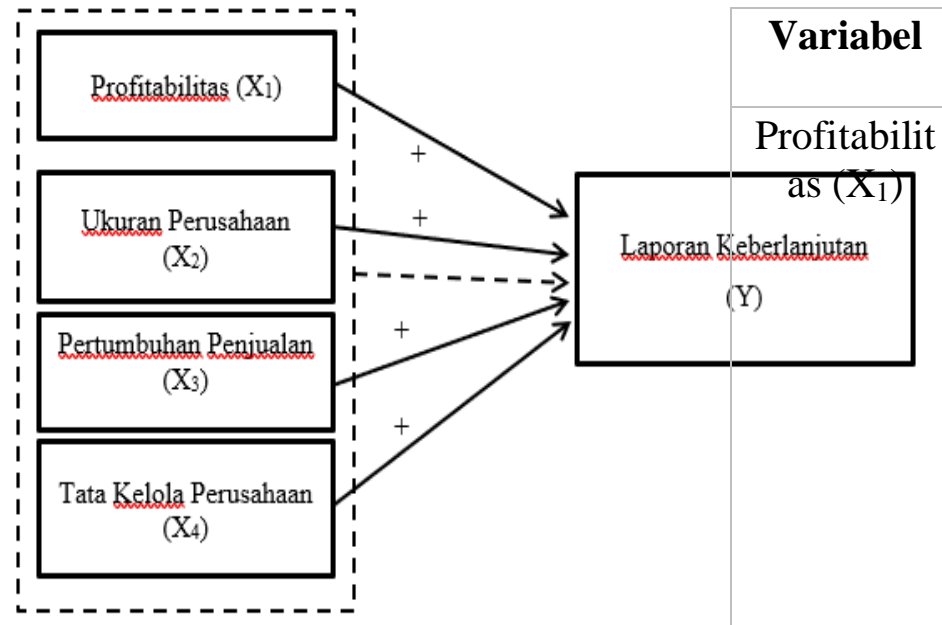

Sumber: Data yang telah diolah (2019)

Gambar 1 Kerangka Pemikiran

Keterangan:

$$
=\text { Pengaruh secara parsial }
$$

\begin{tabular}{|c|c|c|}
\hline $\begin{array}{l}\text { Definisi } \\
\text { Variabel }\end{array}$ & Indikator & $\begin{array}{c}\text { Ska } \\
\text { la }\end{array}$ \\
\hline $\begin{array}{l}\text { Rasio } \\
\text { profitabilitas } \\
\text { merupakan } \\
\text { rasio yang } \\
\text { menggambar } \\
\text { kan } \\
\text { kemampuan } \\
\text { perusahaan } \\
\text { dalam } \\
\text { menghasilka } \\
\text { n laba bersih } \\
\text { dari aktivitas } \\
\text { normal } \\
\text { bisnisnya } \\
\text { (Hery, 2016). }\end{array}$ & $\begin{array}{l}\text { ROA } \\
=\frac{\text { Laba Bersih }}{\text { Total Aset }} \\
(\text { Hery, 2016). }\end{array}$ & \\
\hline Ekuran & Ukuran & Ras \\
\hline
\end{tabular}




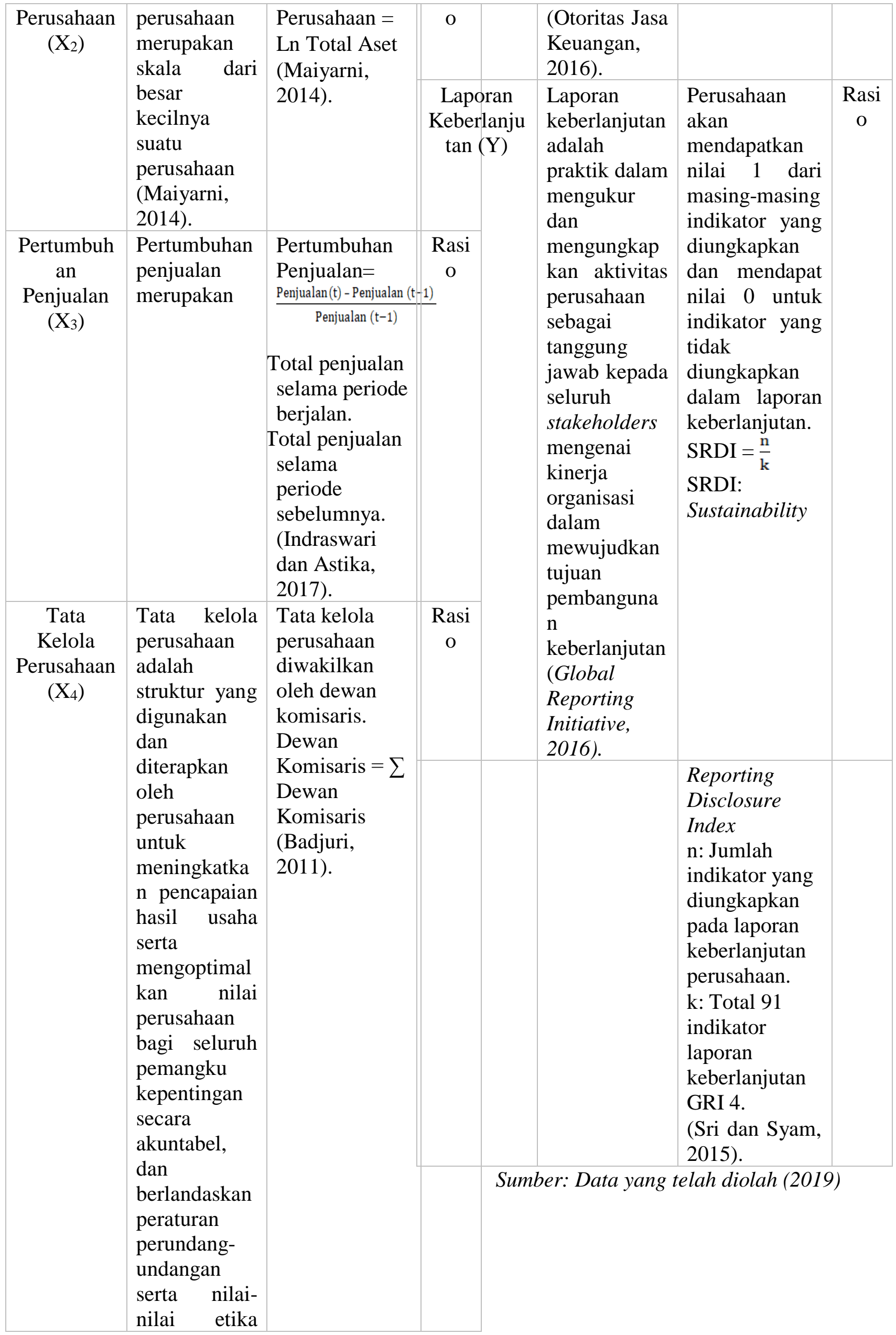




\section{Hasil dan Diskusi}

\section{Analisis Statistik Deskriptif}

Tabel 3 Hasil Analisis Statistik Deskriptif

\begin{tabular}{cccccc}
\hline & $\begin{array}{c}\text { Laporan } \\
\text { Keberlan } \\
\text { jutan }\end{array}$ & $\begin{array}{c}\text { Profitabili } \\
\text { tas }\end{array}$ & $\begin{array}{c}\text { Ukuran } \\
\text { Perusahaan }\end{array}$ & $\begin{array}{c}\text { Pertumbuhan } \\
\text { Penjualan }\end{array}$ & $\begin{array}{c}\text { Tata } \\
\text { Kelola } \\
\text { Perusahaan }\end{array}$ \\
\hline Rata-rata & 0,298 & 0,033 & 30,634 & 0,044 & 5,774 \\
Maksimum & 0,549 & 0,207 & 32,150 & 0,418 & 8 \\
Minimum & 0,110 & $-0,558$ & 27,335 & $-0,378$ & 3 \\
Simpangan & 0,111 & 0,133 & 1,106 & 0,184 & 1,499 \\
Baku & 31 & 31 & 31 & 31 & 31 \\
Total Data & 31 & & & \\
\hline
\end{tabular}

Sumber: Data yang telah diolah (2019)

Pada tabel 3 di atas dapat dilihat hasil uji statistik deskriptif yang terdiri dari nilai rata-rata, maksimum, minimum, dan simpangan baku. Rata-rata profitabilitas pada perusahaan non keuangan yang terdaftar di BEI periode 2016-2017 sebesar 0,033 artinya, rata-rata profitabilitas yang dimiliki perusahaan non keuangan memiliki nilai positif yang mana rata-rata profitabilitas yang dimiliki perusahaan non keuangan sudah baik. Rata-rata ukuran perusahaan pada perusahaan non keuangan sebesar 30,634 artinya, rata-rata ukuran perusahaan yang dimiliki perusahaan non keuangan memiliki logaritma natural dari total aset sebesar 30 sampai 31 . Pertumbuhan penjualan memiliki rata-rata sebesar 0,044 artinya, rata-rata pertumbuhan penjualan perusahaan non keuangan mengalami pertumbuhan dari tahun sebelumnya sebesar 0,044. Tata kelola perusahaan yang dalam penelitian ini diwakilkan oleh dewan komisaris pada perusahaan non keuangan memiliki rata-rata sebesar 5,774 orang. Hal tersebut menunjukkan bahwa rata-rata jumlah dewan komisaris yang dimiliki perusahaan non keuangan adalah sekitar 5 orang sampai 7 orang. Rata-rata pengungkapan laporan keberlanjutan pada perusahaan non keuangan sebesar 0,298. Hal tersebut menunjukkan bahwa rata-rata perusahaan telah mengungkapkan sebanyak 26 sampai 27 poin pengungkapan yang diungkapkan dalam laporan keberlanjutan perusahaan.

\section{Analisis Regresi Data Panel}

Berdasarkan hasil pemilihan model regresi dengan menggunakan uji chow dan uji lagrange multiplier disimpulkan bahwa https://journals.telkomuniversity.ac.id/jaf model common effect merupakan model yang terpilih untuk penelitian ini. Tabel 4 menyajikan hasil regresi data panel menggunakan model common effect.

\section{Tabel 4 Hasil Regresi Data Panel}

\begin{tabular}{ccccc}
\hline Variable & Coefficient & $\begin{array}{c}\text { Std. } \\
\text { Error }\end{array}$ & t-Statistic & Profitability \\
\hline C & 1,502 & 0,525 & 2,859 & 0,008 \\
Profitabilitas & 0,398 & 0,162 & 2,453 & 0,021 \\
Ukuran Perusahaan & $-0,039$ & 0,018 & $-2,154$ & 0,040 \\
Pertumbuhan Penjualan & $-0,213$ & 0,110 & $-1,920$ & 0,066 \\
Tata Kelola Perusahaan & $-0,002$ & 0,014 & $-0,149$ & 0,882 \\
\hline R-squared & 0,317 & Mean dependent var & 0,298 \\
Adjusted $R$-squared & 0,212 & S.D. dependent var & 0,111 \\
S.E. of regression & 0,098 & Akaike info criterion & $-1,650$ \\
Sum squared resid & 0,252 & Schwarz criterion & $-1,418$ \\
Log likelihood & 30,570 & Hannan-Quim criter. & $-1,574$ \\
F-statistic & 3,015 & Durbin-Watson stat & 1,671 \\
Profitabilitas (F-statistic) & 0,036 & &
\end{tabular}

Sumber: Data yang telah diolah (2019)

Berdasarkan tabel 4, nilai adjusted $R$-squared pada penelitian menunjukkan hasil sebesar 0,212 atau 21,2\%. Variabel independen yang terdiri dari profitabilitas, pertumbuhan penjualan, ukuran perusahaan, dan Tata kelola perusahaan dapat menjelaskan variabel dependen laporan keberlanjutan sebesar 0,212 atau 21,2\% sedangkan sisanya yaitu 0,788 atau $78,8 \%$ dijelaskan oleh variabel lain diluar penelitian. Nilai probabilitas F-statistic memiliki nilai sebesar 0,036 nilai tersebut lebih kecil dari tingkat signifikansi 0,05. Kesimpulannya adalah profitabilitas, pertumbuhan penjualan, ukuran perusahaan, dan tata kelola perusahaan secara simultan berpengaruh terhadap pengungkapan laporan keberlanjutan.

Berdasarkan tabel 4, variabel profitabilitas memiliki nilai probabilitas $0,021<0,05$ dan nilai koefisien 0,398 , maka H1 diterima, artinya, profitabilitas berpengaruh positif terhadap tingkat pengungkapan laporan keberlanjutan. Perusahaan yang dapat memaksimalkan kemampuannya dalam menghasilkan laba, akan memiliki alokasi dana keberlanjutan yang cukup untuk digunakan oleh perusahaan dalam melakukan praktik pengungkapan laporan keberlanjutan perusahaannya. Hasil penelitian ini sesuai dengan hipotesis yang dibangun penulis dan dengan hasil Munsaidah (2016) dan Ulfa (2009) menjelaskan bahwa profitabilitas berpengaruh positif terhadap pengungkapan laporan keberlanjutan. 
Variabel ukuran perusahaan memiliki nilai probabilitas $0,040<0,05$ dan nilai koefisien -0,039, maka $\mathrm{H} 2$ diterima, artinya, ukuran perusahaan berpengaruh negatif terhadap pengungkapan laporan keberlanjutan. Ukuran perusahaan yang besar, akan membuat perusahaan cenderung memiliki fokus lain yang dianggap lebih penting daripada membuat laporan keberlanjutan yang lengkap, sebaliknya, ukuran perusahaan yang cenderung kecil akan melakukan pengungkapan laporan keberlanjutan dengan lengkap karena akan menambah citra baik perusahaan dimata masyarakat ataupun investor, sehingga dapat memiliki daya jual tersendiri bagi perusahaannya. Oleh karena itu, ukuran perusahaan dapat memengaruhi pengungkapan laporan keberlanjutan dengan arah negatif.

Variabel pertumbuhan penjualan memiliki nilai probabilitas $0,066>0,05$ dan nilai koefisien -0,213, maka $\mathrm{H} 3$ ditolak, artinya, pertumbuhan penjualan tidak berpengaruh terhadap pengungkapan laporan keberlanjutan. Perubahan pertumbuhan penjualan tidak berpengaruh terhadap tingkat pengungkapan laporan keberlanjutan. Perusahaan yang mengalami pertumbuhan dalam penelitian ini ditunjukkan oleh rasio pertumbuhan penjualan, cenderung lebih memilih menggunakan biaya-biaya untuk kegiatan produksi, sehingga dapat meningkatkan penjualan dan meningkatkan keuntungan perusahaan dibandingkan untuk kegiatan yang berkaitan dengan aktivitas sosial yang nantinya malah akan menambah biaya, sehingga pertumbuhan penjualan tidak mempengaruhi tingkat pengungkapan laporan keberlanjutan. Hasil penelitian ini serupa dengan Indraswari dan Mimba (2017) serta Ulfa (2009) yang mengungkapkan bahwa pertumbuhan penjualan tidak berpengaruh terhadap tingkat pengungkapan laporan keberlanjutan.

Variabel tata kelola perusahaan memiliki nilai probabilitas $0,882>0,05$ dan nilai koefisien -0,002, maka $\mathrm{H} 4$ ditolak, artinya, tata kelola perusahaan tidak berpengaruh terhadap tingkat pengungkapan laporan keberlanjutan. Banyak sedikitnya jumlah tata kelola perusahaan yang dimiliki suatu perusahaan tidak berpengaruh terhadap tingkat pengungkapan laporan keberlanjutan. Variabel dewan komisaris dihitung menggunakan jumlah dewan komisaris yang dimiliki oleh perusahaan kurang mencerminkan kinerja dewan komisaris dalam memonitoring tugas dari dewan direksi sendiri, sehingga tidak adanya pengaruh yang dihasilkan dari jumlah dewan komisaris terhadap tingkat pengungkapan laporan keberlanjutan. Hasil penelitian ini serupa dengan Panggabean (2017) dan Aziz (2014) yang mengungkapkan bahwa tata kelola perusahaan tidak berpengaruh terhadap tingkat pengungkapan laporan keberlanjutan.

\section{Kesimpulan dan Saran}

Berdasarkan hasil pengujian regresi data panel dan analisis deskriptif dapat disimpulkan bahwa secara simultan profitabilitas, pertumbuhan penjualan, ukuran perusahaan, dan tata kelola perusahaan berpengaruh terhadap pengungkapan laporan keberlanjutan. Pengujian secara parsial pada variabel profitabilitas berpengaruh dengan arah positif dan variabel ukuran perusahaan berpengaruh dengan arah negatif terhadap pengungkapan laporan keberlanjutan. Hasil dari variabel pertumbuhan penjualan dan tata kelola perusahaan tidak berpengaruh terhadap pengungkapan laporan keberlanjutan.

\section{Keterbatasan}

Hasil dari penelitian ini menunjukkan terdapat standard error sebesar 78,8\%, sehingga variabel dependen masih dapat dipengaruhi oleh variabel independen lain di luar penelitian. Periode penelitian hanya dilakukan selama dua tahun sehingga jumlah sampel yang diperoleh masih sedikit dan data kurang terdistribusi secara luas.

\section{Saran}

\section{Akademisi}

Penelitian ini diharapkan dapat menarik minat peneliti selanjutnya dalam meneliti beberapa variabel independen lain yang memiliki pengaruh terhadap laporan keberlanjutan seperti manajemen laba, dewan komisaris, dan komite audit. Hal ini 
disarankan karena menurut penelitian yang dilakukan oleh Sinaga (2017), Prayudi pengaruh manajemen laba, dewan komisaris, dan komite audit terhadap tingkat pengungkapan laporan keberlanjutan.

2. Perusahaan

Perusahaan disarankan untuk lebih memerhatikan tingkat profitabilitas perusahaannya, sehingga perusahaan dapat memaksimalkan asetnya agar menghasilkan laba yang dapat dialokasikan untuk melakukan pengungkapan laporan keberlanjutan perusahaan. Hasil dari penelitian ini menunjukkan bahwa rata-rata perusahaan yang memiliki profitabilitas tinggi cenderung memiliki tingkat pengungkapan laporan keberlanjutan yang tinggi.

\section{DAFTAR PUSTAKA}

Aziz, A. (2014). Analisis Pengaruh Good Global Reporting Intiative. (2016). Corporate Governance (GCG) terhadap

Kualitas Sustainability Report. Jurnal Audit dan Akuntansi Fakultas Ekonomi Universitas Tanjungpura, 3(2), 65-84.

Badjuri, A. (2011). Corporate Governance Mechanism, Fundamental Factors, Corporate

Social Responsibility (CSR) Disclosure of A Natural Resource, and Manufactur Company in Indonesian. Dinamika Keuangan dan Perbankan, 3(1), 38-54.

Bursa Efek Indonesia. (2018). Laporan

Keuangan dan Tahunan Perusahaan Tercatat. Jakarta, DKI: Penulis. Diakses dari https://www.idx.co.id/.

Chariri, dan Ghozali. (2013). Teori Akuntansi. Semarang: Badan Penerbit Universitas

Diponegoro.

Enim, M. (2018, Oktober 22) Limbah Eksplorasi PT Bukit Asam, Diduga Cemari

Lingkungan. Publik Zone. Diakses dari http://www.publikzone.com/.
(2017), dan Husain (2016) bahwa terdapat

\section{Bagi investor}

Investor disarankan untuk menjadikan laporan keberlanjutan sebagai satu diantara pertimbangan dalam membuat keputusan investasi. Investor dapat memerhatikan tingkat profitabilitas perusahaan dikarenakan hasil penelitian menunjukkan bahwa perusahaan yang memiliki profitabilitas tinggi cenderung memiliki tingkat pengungkapan laporan keberlanjutan yang tinggi sehingga, perusahaan tersebut akan diterima dengan baik oleh masyarakat dan dapat menjalankan operasi perusahaannya secara berkelanjutan.

Rangkaian Standar Pelaporan Keberlanjutan GRI 2016

Terkonsolidasi. Amsterdam: Global Reporting Initiative. Diakses dari http://www.globalreporting.org/.

Hery. (2016). Analisis Laporan Keuangan. Bandung: Grasindo.

Husain, S. (2016). Pengaruh Manajemen Laba terhadap Pengungkapan Corporate Social Responsibility pada Perusahaan Pertambangan yang Listing di Bursa Efek Indonesia Periode 2010-2014 Profitabilitassiding Simposium Nasional Akuntansi Vokasi, 5(1), 10 12.

Indraswari, dan Astika. (2015).

Pengaruh Profitabilitas, Ukuran Perusahaan, dan Kepemilikan Saham Publik terhadap Pengungkapan Corporate Social Responsibility Perusahaan Makanan dan Minuman Bursa Efek Indonesia Periode 20102012. E- Jurnal Akuntansi Universitas Udayana, 11(1), 289-302.

Indraswari, dan Mimba. (2017).

Pengaruh Profitabilitas, Pertumbuhan 
Perusahaan, Kapitalisasi Pasar, dan

Kepemilikan Saham Publik pada Tingkat Pengungkap CSR.Udayana, E-jurnal Akuntansi Universitas, 20(2), 8-11.

Kurniawan. (2017, November 19).Sustainability Report (SR) di Indonesia Sepi Peminat. Majalah CSR. Diakses dari http://www.majalahcsr.id/.

Luqman, A. (2017, Oktober 23). Aktivis Lingkungan: Pabrik PT Semen Indonesia Diduga Merusak Teluk Balikpapan. Berita Nusantara. Diakses dari https://kbr.id/nusantara/.

Maiyarni, R., dan Erwati, M. (2014) Pengaruh Profitabilitas, Ukuran Perusahaan,Likuiditas, dan Leverage terhadap Pengungkapan Corporate Social Responsibility (CSR) pada PerusahaanLQ 45 yang Terdaftar di Bursa Efek Indonesia Periode 20092012. Jurnal Cakrawala Akuntansi, 6(1), 79-94.

Munsaidah, S., Andini, R., dan Supriyanto, A.(2016) Analisis Pengaruh Firm Size, Age, Profitabilitas, Leverage, dan Growth Perusahaan terhadap Corporate Social Rerponsibility (CSR) pada Perusahaan Profitabilitaspert dan Real Estate yangTerdaftar di Bursa Efek Indonesia Pada Tahun 2010-2014. Journal of Accounting, 2(2), 111.Otoritas Jasa Keuangan. (2016). Tentang Perseroan Terbatas. Jakarta, DKI: Penulis Diakses dari https://www.ojk.go.id/.

Panggabean, E. Y. (2017). Analisis Pengaruh Faktor-Faktor Fundamental dan Mekanisme Tata Kelola Perusahaan terhadap Pengungkapan Corporate Social Responsibility (CSR). Jurnal Riset Akuntansi \& Bisnis, 17(1), 3-16.

Prayudi, M. A. (2017). Pengaruh Leverage, Ukuran Perusahaan Komite Audit, dan Kepemilikan Institusional terhadap Luas Pengungkapan Sustainability Report (Studi Empiris Perusahaan Yang Mengikuti Isra Periode 2013-2015). Jurnal Ilmiah Mahasiswa Akuntansi Undiksha, 8(2), 1011.

Putra. (2016). Peran Dewan Komisaris terhadap Pengungkapan Corporate Social Responsibility dengan Profitabilitas sebagai Variabel Moderator. Jurnal Manajemen \& Bisnis, 13(1), 247.

Sinaga, K. J. (2017). The Effect of Profitability, Activity Analysis, Industrial Type, and Good Corporate Governance Mechanism on The Disclosure of Sustainability Report AAJ: Accounting Analysis Journal, 6(3), 347-358.

Sri, A., dan Syam, D. (2013). Pengaruh Karakteristik Perusahaan terhadap Praktik Pengungkapan Laporan Keberlanjutan dalam Laporan Tahunan Perusahaan Publik di Indonesia. Jurnal Review Akuntansi dan Keuangan, 3(1), 403.

Ulfa, M. (2009). Pengaruh Karakteristik Perusahaan terhadap Corporate Social Responsibility Disclosure. Universitas Islam Indonesia, 5(2), 326-344. 